Arq. Bras. Med. Vet. Zootec., v.56, n.2, p. 251-257, 2004

\title{
Estimates of correction factors for lactation length and genetic parameters for milk yield in buffaloes
}

\author{
[Estimativas de fatores de correção para duração da lactação e de parâmetros \\ genéticos da produção de leite de búfalas] \\ H. Tonhati ${ }^{1}$, M.F.C. Muñoz ${ }^{2}$, J.M.C. Duarte ${ }^{1}$, R.H. Reichert ${ }^{3}$, J.A. Oliveira ${ }^{1}$, A.L.F. Lima ${ }^{1}$ \\ ${ }^{1}$ Faculdade de Ciências Agrárias e Veterinária - FCAV \\ Universidade Estadual Paulista- UNESP \\ Via de Acesso Prof. Paulo D. Castellane s/n \\ 14884-900 - Jaboticabal, SP \\ Facultad de Ciencias Agrárias. Universidad de Antioquia - Medellín, Colombia \\ ${ }^{3}$ Secretaria da Agricultura e Abastecimento do Estado de São Paulo - Registro, SP
}

\begin{abstract}
RESUMO
Estimaram-se fatores de correção para produção de leite aos 90, 240, 270 e 305 dias de lactação e parâmetros genéticos e de ambiente da produção de leite ajustada para esses períodos de lactação, utilizando-se 3888 lactações de 1630 búfalas, controladas entre 1987 e 2001, em 10 rebanhos do Estado de São Paulo. Os parâmetros genéticos foram estimados por meio do método da máxima verossimilhança restrita, livre de derivadas, aplicado a um modelo animal com medidas repetidas. As estimativas de herdabilidade para produção de leite corrigida para 90, 240, 270 e 305 dias de lactação foram 0,17; 0,15; 0,14 e 0,14 , respectivamente. Nessa mesma ordem de apresentação, as estimativas de repetibilidade foram 0,$40 ; 0,44 ; 0,41$ e 0,41 . As estimativas de correlação genética entre essas produções de leite corrigidas variaram de 0,96 a 1,00. Os fatores de correção multiplicativos para as diferentes classes de duração da lactação foram eficientes para ajustar a produção de leite aos 90, 240, 270 e 305 dias de lactação.
\end{abstract}

Palavras-chave: búfalo, duração da lactação, produção de leite

\begin{abstract}
Correction factors for milk yield at 90, 240, 270 and 305 days of lactation of buffaloes and genetic and environmental parameters for milk yield of these lactation periods were estimated. The data used consisted of 3888 lactation records of 1630 buffaloes from 10 herds reared in the State of São Paulo. Genetic parameters were estimated by the derivative free restricted maximum likelihood method, fitting an animal repeatability model. Heritability estimates for milk yield corrected for 90, 240, 270 and 305 days of lactation were $0.17,0.15,0.14$ and 0.14 , respectively. In this same order, repeatability estimates were 0.40, 0.44, 0.41 and 0.41. The genetic correlation estimates between these corrected milk yields ranged from 0.96 to 1.00. The multiplicative correction factors for the different classes of lactation lengths were efficient for adjustment of milk yield at 90, 240, 270 and 305 days of lactation.
\end{abstract}

Keywords: buffalo, lactation length, milk yield

Apoio financeiro: FAPESP/CNPq

Recebido para publicação em 21 de fevereiro de 2003

Recebido para publicação, após modificações, em 29 de dezembro de 2003

E-mail: tonhati@fcav.unesp.br 


\section{INTRODUCTION}

Milk yield of a cow is the result of environmental and genetics effects. To obtain accurate genetic evaluations, milk yield records should be adjusted for known environmental factors either by previously calculated adjustment factors or by inclusion in the model.

Aside from genetics, factors affecting milk yield per lactation include management and environmental factors such as dry period before calving, calving-conception period, days milking, number of daily milkings, feeding system, milking system, age at calving, calving order etc. Correction for these effects reduces environmental variance, allowing a reliable comparison of individuals submitted to different environmental conditions (Searle, 1962; Miller, 1973).

In general, correction methods are based on factors of the additive or multiplicative types applied to milk yield records. In 1920, Gowen, cited by Searle and Henderson (1959), was the first to develop correction factors for total milk yield of Holstein and Jersey cows as a function of cow's age at calving. Later, several investigators developed correction factors also for cow's age at calving and lactation length for different species and breeds in different countries. Work of this type concerning buffaloes was performed by Khan (1986) and Iqbal (1996), cited by Khan and Chaudry (2001).

On this basis, the objective of the present study was to estimate correction factors for milk yield at 90,240, 270 and 305 days of lactation for buffaloes and genetic parameters for these traits.

\section{MATERIALS AND METHODS}

Buffaloes milk yield records were obtained from monthly milk test day recorded by the Departamento de Zootecnia/FCAV, Jaboticabal, SP, from 1987 to 2001 in 10 herds raised in the State of São Paulo. These herds consist of animals of the Murrah breed raised on pastures. The animals received a feed supplementation based on ground sugar cane as bulk, and a concentrate consisting of cotton seed, barley and soybean, especially during the dry period from April to September. A total of 3888 lactations were analyzed. Total milk yield up to 305 lactation days $\left(\mathrm{MY}_{305}\right)$ was calculated using a method officially recognized by the Ministry of Agriculture (Brasil, 1986). Milk yields up to 90, 240 and 270 lactation days $\left(\mathrm{MY}_{90}, \mathrm{MY}_{240}\right.$ and $\mathrm{MY}_{270}$, respectively) were also calculated using the previous procedure, modifying only the terms of the truncation of sum of milk yield on the different days.

For $\mathrm{MY}_{305}, \mathrm{MY}_{270}$ and $\mathrm{MY}_{240}$ lactations of less than 100 days were eliminated and for $\mathrm{MY}_{90}$ lactations of less than 50 days in milk were eliminated. Records of abnormal lactations or records for cows older than 175 months at calving were excluded. Contemporary groups (farm-year) with less than 10 lactations were eliminated.

To estimate the correction factors for MY90, MY240, MY270 and MY305 lactation length classes were established at ten day intervals, as shown in Table 1. The correction factors were estimated using the following model:

$$
\begin{aligned}
& \mathrm{y}_{\mathrm{ijkl}}=\mu+\mathrm{h}_{\mathrm{i}}+\mathrm{n}_{\mathrm{j}}+\mathrm{d}_{\mathrm{k}}+\mathrm{b}_{1}\left(\mathrm{I}_{\mathrm{ijk} \mathrm{l}}-\overline{\mathrm{I}}\right)+\mathrm{b}_{2}\left(\mathrm{I}_{\mathrm{ijk} \mathrm{k}}-\overline{\mathrm{I}}\right)^{2} \\
& +\mathrm{a}_{1}+\mathrm{p}_{1}+\mathrm{e}_{\mathrm{ijkl}} \text {, where: } \\
& \mathrm{y}_{\mathrm{ijkl}}=\text { dependent variables }\left(\mathrm{MYT}, \mathrm{MYC}_{90}\right. \text {, } \\
& \mathrm{MYC}_{240}, \mathrm{MYC}_{270} \text { and } \mathrm{MYC}_{305} \text { ) } \\
& \mu=\text { general mean; } \\
& h_{i}=\text { fixed effect of the } i^{\text {th }} \text { contemporary group; } \\
& n_{j}=\text { fixed effect of the } j^{\text {th }} \text { calving order; } \\
& \mathrm{d}_{\mathrm{k}}=\text { fixed effect of the } \mathrm{k}^{\text {th }} \text { lactation length class; } \\
& b_{1} \quad \text { e } \quad b_{2}=\text { linear and quadratic regression } \\
& \text { coefficients for milk yield as a function of } \\
& \text { cow's age at calving (months); } \\
& \mathrm{I}_{\mathrm{ijkl}}=\text { age at calving of the } 1^{\text {th }} \text { cow; } \\
& \overline{\mathrm{I}}=\text { mean cow's age at calving; } \\
& \mathrm{a}_{1}=\text { random effect of the } 1^{\text {th }} \text { cow, with NID } \\
& \left(0, \sigma_{\mathrm{a}}^{2}\right) \text {; } \\
& \mathrm{p}_{\mathrm{l}}=\text { permanent environment random effect of the } \\
& 1^{\text {th }} \text { cow, with } \operatorname{NID}\left(0, \sigma_{p}^{2}\right) \text {; } \\
& \mathrm{e}_{\mathrm{ijkl}}=\text { random residual effect with } \operatorname{NID}\left(0, \sigma_{\mathrm{e}}^{2}\right)
\end{aligned}
$$


Estimates of correction factors...

Table 1. Distribution of lactations into classes of lactation length for buffaloes reared in the State of São Paulo

\begin{tabular}{|c|c|c|c|c|c|c|c|c|}
\hline & \multicolumn{2}{|c|}{$50-90$ days of lactation } & \multicolumn{2}{|c|}{$\begin{array}{l}\text { 100-240 days of } \\
\text { lactation }\end{array}$} & \multicolumn{2}{|c|}{$\begin{array}{l}\text { 100-270 days of } \\
\text { lactation }\end{array}$} & \multicolumn{2}{|c|}{$\begin{array}{c}\text { 100-305 days of } \\
\text { lactation }\end{array}$} \\
\hline Number of records & & & & 359 & & 312 & & 3322 \\
\hline Mean milk yield (kg) & & & & 365 & & 456 & & 502 \\
\hline Mean lactation length (days) & & \pm 9.79 & 208 & \pm 40.97 & 232 & $5 \pm 43.12$ & 244 & $0 \pm 51.98$ \\
\hline $\begin{array}{l}\text { Classe of lactation } \\
\text { length }\end{array}$ & $\mathrm{N}$ & $\begin{array}{c}\text { Mean } \\
(\mathrm{kg} \text { milk) }\end{array}$ & $\mathrm{N}$ & $\begin{array}{c}\text { Mean } \\
(\mathrm{kg} \text { milk })\end{array}$ & $\mathrm{N}$ & $\begin{array}{c}\text { Mean } \\
(\mathrm{kg} \text { milk }) \\
\end{array}$ & $\mathrm{N}$ & $\begin{array}{c}\text { Mean } \\
(\mathrm{kg} \text { milk }) \\
\end{array}$ \\
\hline $50-59$ & 100 & 381.7 & & & & & & \\
\hline $60-69$ & 349 & 444.3 & & & & & & \\
\hline $70-79$ & 849 & 530.3 & & & & & & \\
\hline $80-90$ & 2046 & 636.9 & & & & & & \\
\hline $100-109$ & & & 52 & 773.9 & 30 & 882.2 & 30 & 882.2 \\
\hline $110-119$ & & & 45 & 708.3 & 39 & 735.9 & 39 & 735.9 \\
\hline $120-129$ & & & 56 & 777.1 & 33 & 801.3 & 33 & 801.3 \\
\hline $130-139$ & & & 68 & 832.7 & 48 & 857.3 & 48 & 857.3 \\
\hline $140-149$ & & & 76 & 922.4 & 71 & 934.6 & 71 & 934.6 \\
\hline $150-159$ & & & 72 & 1021.7 & 63 & 1036.6 & 60 & 1040.6 \\
\hline $160-169$ & & & 72 & 973.1 & 62 & 967.1 & 62 & 967.1 \\
\hline $170-179$ & & & 103 & 1008.2 & 90 & 1006.2 & 87 & 1005.5 \\
\hline $180-189$ & & & 127 & 1047.7 & 98 & 1061.4 & 96 & 1058.7 \\
\hline 190-199 & & & 135 & 1081.0 & 93 & 1088.7 & 90 & 1092.3 \\
\hline $200-209$ & & & 166 & 1261.9 & 109 & 1203.2 & 105 & 1210.6 \\
\hline $210-219$ & & & 343 & 1359.7 & 140 & 1259.3 & 132 & 1252.3 \\
\hline $220-229$ & & & 656 & 1474.3 & 157 & 1344.1 & 146 & 1335.7 \\
\hline $230-239$ & & & 1388 & 1566.3 & 216 & 1373.9 & 190 & 1354.0 \\
\hline $240-249$ & & & & & 432 & 1520.4 & 332 & 1467.9 \\
\hline $250-259$ & & & & & 583 & 1598.8 & 288 & 1518.5 \\
\hline $260-269$ & & & & & 1048 & 1727.7 & 260 & 1556.5 \\
\hline $270-279$ & & & & & & & 253 & 1749.7 \\
\hline $280-289$ & & & & & & & 298 & 1833.4 \\
\hline $290-299$ & & & & & & & 317 & 1783.7 \\
\hline $300-305$ & & & & & & & 385 & 1981.2 \\
\hline
\end{tabular}

$\mathrm{N}=$ number of records

The relationship consisted of 7396 animals, 2062 of which presented a mean inbreeding coefficient of $4.8 \%$.

The solutions for the lactation length classes were obtained using the MTDFREML according Boldman et al. (1993). Estimates for lactation length classes were obtained by adding the means to the solutions of the lactation length classes, considering the equations of the model. The estimates were smoothed using a first degree polynomial for each grouping, yielding a coefficient of determination $\left(\mathrm{R}^{2}\right)$ of 0.95 to 0.99 . The correction factors were obtained by the expression:

$\mathrm{F}_{1}=\hat{d}_{l b} / \hat{d}_{l^{\prime}}$, where:

$F_{1}$ is the multiplicative correction factor for the $i^{\text {th }}$ class of lactation length 1 ', $\hat{d}_{l b}$ is the adjusted estimate of milk yield for the base class of lactation length, and $\hat{d}_{l^{\prime}}$ is the adjusted estimate of mean yield for the observations obtained for cows with lactation length 1'.

These correction factors were applied to milk yield for different lactation lengths, yielding productions corrected for 90, 240, 270 and 305 days $\left(\mathrm{MYC}_{90} . \mathrm{MYC}_{240} . \mathrm{MYC}_{270}\right.$ and $\mathrm{MYC}_{305}$, respectively. These yields were compared with non-corrected yields by linear regression analysis of the effect of lactation length in order to determine the reduction in variation associated with lactation length (Searle, Henderson, 1960; Miller et al., 1968; Searle, 1962).

For the estimates of genetic parameters of milk yield corrected for different lactation days $\left(\mathrm{MYC}_{90}, \quad \mathrm{MYC}_{240}, \quad \mathrm{MYC}_{270}\right.$ and $\left.\mathrm{MYC}_{305}\right)$ (co)variance components were estimated by 
multiple trait analysis using the MTDFREML program developed by Boldman et al. (1993).

The model for analysis included fixed effects of contemporary group (herd-year) and calving order, the covariable cow's age at calving (linear and quadratic effects) and random and permanent environmental effects of cow. Thus, the model adopted, represented in the matrix form, was: $\mathrm{y}=\mathrm{X} \beta+\mathrm{Za}+\mathrm{Wp}+\mathrm{e}$, where: $\mathrm{y}$ is the vector of each trait (MYT, $\mathrm{MYC}_{90}$, $\mathrm{MYC}_{240}, \mathrm{MYC}_{270}$ and $\mathrm{MYC}_{305}$ ), $\beta$ is the vector the fixed effects, $a$ is the vector of the effects the cow, $p$ is the vector of the permanent environment effects of cow and $\mathrm{e}$ is the vector of residuals. $\mathrm{X}, \mathrm{Z}$ and $\mathrm{W}$ are incidence matrices for $\beta$, a and $p$, respectively.

The model is based on the following assumptions:

$\mathrm{E}\left[\mathrm{a}_{\mathrm{i}}\right]=\mathrm{E}\left[\mathrm{p}_{\mathrm{i}}\right]=\mathrm{E}\left[\mathrm{e}_{\mathrm{i}}\right]=0 \mathrm{e} \mathrm{V} \mathrm{r}=\left[\begin{array}{c}\mathrm{a}_{1} \\ \mathrm{a}_{2} \\ \mathrm{p}_{1} \\ \mathrm{p}_{2} \\ \mathrm{e}_{1} \\ \mathrm{e}_{2}\end{array}\right]=\left[\begin{array}{cccccc}\mathrm{A} \sigma_{\mathrm{a}_{1}}^{2} & \mathrm{~A} \sigma_{\mathrm{a}_{1} \mathrm{a}_{2}} & 0 & 0 & 0 & 0 \\ \mathrm{~A} \sigma_{\mathrm{a}_{1} \mathrm{a}_{2}} & \mathrm{~A} \sigma_{\mathrm{a}_{2}}^{2} & 0 & 0 & 0 & 0 \\ 0 & 0 & \mathrm{I} \sigma_{\mathrm{p}_{1}}^{2} & \mathrm{I} \sigma_{\mathrm{p}_{1} \mathrm{p}_{2}} & 0 & 0 \\ 0 & 0 & \mathrm{I} \sigma_{\mathrm{p}_{1} \mathrm{p}_{2}}^{2} & \mathrm{I} \sigma_{\mathrm{P}_{2}}^{2} & 0 & 0 \\ 0 & 0 & 0 & 0 & \mathrm{I} \sigma_{\mathrm{e}_{1}}^{2} & \mathrm{I} \sigma_{\mathrm{e}_{1} \mathrm{e}_{2}} \\ 0 & 0 & 0 & 0 & \mathrm{I} \sigma_{\mathrm{e}_{1} \mathrm{e}_{2}} & \mathrm{I} \sigma_{\mathrm{e}_{2}}^{2}\end{array}\right]$,

where: 0 is the null matrix, $\mathrm{A}$ is the relationship matrix, $I$ is the identity matrix, $\sigma_{\mathrm{a}_{\mathrm{i}}}^{2}, \sigma_{\mathrm{p}_{\mathrm{i}}}^{2}$ and $\sigma_{\mathrm{e}_{\mathrm{i}}}^{2}$ are the variances of the additive genetic, the permanent environmental and the residual effects for the trait $\mathrm{i}(\mathrm{i}=1,2)$, respectively, and $\sigma_{\mathrm{a}_{1} \mathrm{a}_{2}}$, $\sigma_{\mathrm{p}_{1} \mathrm{p}_{2}}^{2}$ and $\sigma_{\mathrm{e}_{1} \mathrm{e}_{2}}$ are the covariances of the additive genetic, the permanent environmental and residual effects between traits 1 and 2, respectively.

Multiple trait analyses were also performed between corrected milk yields and non-corrected total milk yield, with the lactation length covariable being included in the model in addition to the fixed and random effects mentioned earlier.

\section{RESULTS AND DISCUSSION}

The correction factors estimated for each lactation length class are presented in Table 2 and were applied to the original data base. Mean milk yields corrected for 90, 240, 270 and 305 days of lactation $\left(\mathrm{MYC}_{90}, \mathrm{MYC}_{240}, \mathrm{MYC}_{270}\right.$ and
$\left.\mathrm{MYC}_{305}\right)$ were $629.73 \pm 227.11,1535.00 \pm 566.19$, $1712.46 \pm 647.86$ and $1908.94 \pm 701.04 \mathrm{~kg}$, respectively. The gradual differences in mean milk yield on the different days of truncation were due to the application of the estimated correction factors and to the sum of milk yield on each date. The observed uncorrected total milk yield was $1532.68 \pm 660.87 \mathrm{~kg}$, a value similar to that for $\mathrm{MYC}_{240}$. This similarity can be attributed to mean lactation length $(254.37 \pm 65.21$ days $)$, which was close to the date of truncation in question (240 days).

In Italy, milk yield corrected for 270 days was $2286.8 \pm 492.1 \mathrm{~kg}$ (Rosati, Van Vleck, 2002). In Pakistan, Khan and Chaudry (2001), working with 2704 lactation records of Nilli-Ravi buffaloes, obtained a total uncorrected milk yield of $1984.40 \mathrm{~kg}$, with a mean lactation length of 266.6 days. When these milk productions were adjusted using correction factors for 308 days, mean milk yield increased to $2139 \mathrm{~kg}$. The higher milk production in Italy and other European countries and in India was probably due to differences in animal feeding, lactation length and herd genetic constitution. 
Table 2. Multiplicative correction factors for milk yield at 90, 240, 270 and 305 days of lactation of buffaloes reared in the State of São Paulo

\begin{tabular}{|c|c|c|c|c|}
\hline $\begin{array}{l}\text { Classe of lactation } \\
\text { length }\end{array}$ & $\begin{array}{c}\text { 50-90 days of } \\
\text { lactation }\end{array}$ & $\begin{array}{l}\text { 100-240 days of } \\
\text { lactation }\end{array}$ & $\begin{array}{l}100-270 \text { days of } \\
\text { lactation }\end{array}$ & $\begin{array}{l}\text { 100-305 days of } \\
\text { lactation }\end{array}$ \\
\hline $50-59$ & 1.71260 & & & \\
\hline $60-69$ & 1.38388 & & & \\
\hline $70-79$ & 1.6103 & & & \\
\hline $80-90$ & 0.99999 & & & \\
\hline $100-109$ & & 2.55339 & 3.24699 & 3.34089 \\
\hline $110-119$ & & 2.28085 & 2.91884 & 2.99083 \\
\hline $120-129$ & & 2.06088 & 2.58780 & 2.70717 \\
\hline $130-139$ & & 1.87960 & 2.32420 & 2.47266 \\
\hline $140-149$ & & 1.72764 & 2.10934 & 2.27554 \\
\hline $150-159$ & & 1.59841 & 1.93084 & 2.10752 \\
\hline $160-169$ & & 1.48717 & 1.78020 & 1.96261 \\
\hline $170-179$ & & 1.39040 & 1.65136 & 1.83635 \\
\hline $180-189$ & & 1.30546 & 1.53991 & 1.72535 \\
\hline $190-199$ & & 1.23030 & 1.44255 & 1.62701 \\
\hline $200-209$ & & 1.16332 & 1.35678 & 1.53927 \\
\hline $210-219$ & & 1.10326 & 1.28063 & 1.46051 \\
\hline $220-229$ & & 1.04910 & 1.21257 & 1.38941 \\
\hline $230-239$ & & 1.00000 & 1.15138 & 1.32492 \\
\hline $240-249$ & & & 1.09607 & 1.26615 \\
\hline $250-259$ & & & 1.04583 & 1.21237 \\
\hline $260-269$ & & & 1.00000 & 1.16298 \\
\hline $270-279$ & & & & 1.11745 \\
\hline $280-289$ & & & & 1.07535 \\
\hline $290-299$ & & & & 1.03631 \\
\hline $300-305$ & & & & 1.00000 \\
\hline
\end{tabular}

For the determination of the effect of correction factors on milk yield, regression analyses were performed for uncorrected yields, including the linear effect of lactation length. These analyses presented coefficients of determination $\left(\mathrm{R}^{2}\right)$ of $0.12,0.20,0.21$ and 0.27 for $\mathrm{MY}_{90}, \mathrm{MY}_{240}$, $\mathrm{MY}_{270}$ and $\mathrm{MY}_{305}$, respectively; and $\mathrm{R}^{2}$ of 0.005 , $0.0003,0.017$ and 0.005 for corrected $\mathrm{MYC}_{90}$, $\mathrm{MYC}_{240}, \mathrm{MYC}_{270}$ and $\mathrm{MYC}_{305}$, respectively, with the reduction in $\mathrm{R}^{2}$ showing that the effect of lactation length was removed when the estimated correction factors were used (Table 2).

Table 3 lists the heritability and genetic correlation estimates obtained for milk yield at different times during lactation.

The heritability estimates differed little from that obtained for buffaloes by Rosati and Van Vleck (2002) in Italy, which was 0.14 for adjusted milk yield at 270 days and that obtained by Kuralkar and Raheja (1997), which was $0.22 \pm 0.05$ for milk yield adjusted for 305 days for buffaloes reared on military farms in India.
Table 3. Heritability (diagonal) and genetic correlation (above the diagonal) estimates for total milk yield (MYT) and yields corrected for 90 (MYC90), 240 (MYC240), 270 (MYC270) and 305 (MYC305) days of lactation

\begin{tabular}{|c|c|c|c|c|c|}
\hline & MYT & MYC90 & MYC240 & MYC270 & MYC305 \\
\hline MYT & 0.19 & 0.97 & 0.92 & 0.87 & 0.92 \\
\hline MYC90 & & 0.17 & 0.99 & 0.96 & 0.96 \\
\hline MYC240 & & & 0.18 & 1.00 & 1.00 \\
\hline MYC270 & & & & 0.14 & 1.00 \\
\hline MYC305 & & & & & 0.14 \\
\hline
\end{tabular}

The magnitude of the heritability estimates reported in the literature varies due to differences in estimation methods and in the populations under study. In the present study, the heritability estimates were of low magnitude, indicating that only a relatively small part of the variation observed in the traits studied can be attributed to additive genetic effects of the genes. Consequently, these traits are highly affected by the environment and therefore it is necessary to improve management practices in order to increase milk production. 
The heritability estimates of higher magnitude were for $\mathrm{MYC}_{90}(0.17)$ and $\mathrm{MYC}_{240}(0.18)$. In the case of $\mathrm{MYC}_{90}$, the result can be explained by the lower effect of environment, which is less expressive at the beginning of lactation. In the case of $\mathrm{MYC}_{240}$, this can be attributed to the fact that in this truncation point (240 days) there was the largest number of completed lactations, with no need to apply correction factors. As a consequence, the effect of lactation length was eliminated for most lactations.

The genetic correlations between corrected milk yields ranged from 0.96 to 1.00 , indicating that in all cases there was a high positive linear association between the genetic (additive) values of the individuals.

The repeatability estimates obtained for MYT, $\mathrm{MYC}_{90}, \mathrm{MYC}_{240}, \mathrm{MYC}_{270}$ and $\mathrm{MYC}_{305}$ and for the correlations between permanent environment and temporary environment and these milk yields are presented in Table 4. The repeatability estimates, which ranged from 0.40 to 0.45 , agree with literature values (Marques, 1991; Rosati, Van Vleck, 2002) and indicate that past production may be indicative of future lactations, as an aid for selection.

Table 4. Repeatability (diagonal) and correlation estimates of permanent environment (above the diagonal) and temporary environment (below the diagonal) for total milk yield (MYT) and yields corrected for 90 (MYC90), 240 (MYC240), 270 (MYC270) and 305 (MYC305) days of lactation

\begin{tabular}{lccccc}
\hline & MYT & MYC90 & MYC240 & MYC270 & MYC305 \\
\hline MYT & 0.41 & 0.89 & 0.97 & 1.00 & 0.96 \\
cbMYC90 & 0.59 & 0.40 & 0.97 & 0.98 & 0.94 \\
MYC240 & 0.64 & 0.78 & 0.45 & 1.00 & 1.00 \\
MYC270 & 0.52 & 0.72 & 0.92 & 0.41 & 1.00 \\
MYC305 & 0.56 & 0.79 & 0.94 & 0.96 & 0.41 \\
\hline
\end{tabular}

The correlations of permanent and temporary environment (residual) were high. The former ranged from 0.87 to 0.99 and the latter were a little lower, i.e., 0.72 to 0.96 . These values suggest that large part of the environmental factors, which result from permanent circumstances in the first case and from temporary circumstances in the second; including non-additive genetic effects, simultaneously affect the corrected lactations at different days.
In order to obtain genetic gain for $\mathrm{MYC}_{305}$, indirect selection can be applied based on yields at 90,240 or 270 days of lactation, which can be genetically evaluated in a more precise manner due to the larger number of animals involved, with evaluation being obtained within a shorter period of time than for yield at 305 days, with a consequent reduction of costs and time. On the other hand, animals lactating for only 50 days could be included in the genetic evaluations performed at $\mathrm{MYC}_{90}$ in order to accumulate more information for animal selection and to improve the precision of milk yield estimates, minimizing errors due to culling of incomplete or nonterminated lactations (Fimland, 1983).

As an alternative, selection programs could consider yields with a lactation length closer to the herd mean, as done in genetic breeding programs in Italy (Rosati, Van Vleck, 2002), which use milk yield corrected for 270 days. In the present study, mean lactation length was $254.37 \pm 65.21$ days, thus suggesting that selection programs for milk yield in buffalos reared in the State of São Paulo could consider productions corrected for eight or nine months of lactation.

\section{CONCLUSIONS}

The multiplicative correction factors for the different classes of lactation lengths were efficient for the adjustment of milk yield at 90, 240, 270 and 305 days of lactation. The heritability estimates for the four corrected productions were low, indicating that the perspectives of genetic gain by selection are low. The genetic correlations between productions were high; thus, by selecting for any period of production, the breeder will be selecting for all the remaining ones. The repeatability estimates were medium to high, indicating that the future performance of cows can be predicted from past performance.

\section{REFERENCES}

BOLDMAN, K.G.; KRIESE, L.A.; VAN VLECK, L.D. et al. A manual for the use of MTDFREML: a set of programs of variances and covariances. Lincoln: Department of Agriculture Research Service, 1993. 120p. 
BRASIL. Ministério da Agricultura, Abastecimento e Reforma Agrária. Normas técnicas para execução do serviço de controle leiteiro em bovídeos. Diário Oficial da União, Brasília, DF, 15 out., n.195, seção 1, p.15321535, 1986.

FIMLAND, E. Some properties of using the additive genetic relationship in the mixed model technique. Z. Tierz. Zuechtungsbiol, v.100, p.331-374, 1983.

KHAN, M.S.; CHAUDRY, H.Z. Prediction of lactation yield from last-record day and average daily yield in Nili-Ravi buffaloes. Bulletin of the FAO Inter-regional Cooperative Research Network on Buffalo, v.15, p.7-10, 2001.

KURALKAR, S.V.; RAHEJA, K.L. Relationships among early performance, lifetime production and reproduction traits in Murrah buffaloes. Indian J. Anim. Sci., v.67, p.798-801, 1997.

MARQUES, J.R.F. Avaliação genéticoquantitativa de alguns grupamentos raciais de bubalinos (Bubalus bubalis, L). 1991. 134f. Tese
(Doutorado)- Instituto de Biociências, Universidade Estadual Paulista, Botucatu, SP.

MILLER, R.H.; McDANIEL B.T.; MYOWMAN, R.D. Effects of errors in the age adjustment of first lactations. J. Dairy Sci., v.51, p.378-384, 1968.

MILLER, P. A recent study of age adjustment. $J$. Dairy Sci., v.56, p.952-959, 1973.

ROSATI, A.; VAN VLECK, L.D. Estimation of genetic parameters for milk, fat, protein and mozzarella cheese production for the Italian river buffalo Bubalus bubalis population. Liv. Prod. Sci., v.74, p.185-90, 2002.

SEARLE, S.R. Age and herd effects in New Zealand dairy cow records. J. Dairy Sci., v.45, p.82-85, 1962.

SEARLE, S.R.; HENDERSON, C.R. Establishing age-correction factors related to the level of herd production. J. Dairy Sci., v. 42, p.824-835, 1959.

SEARLE, S.R.; HENDERSON, C.R. Judging the effectiveness of age-correction factors. J. Dairy Sci., v. 43, p.966-974, 1960. 